\title{
EVALUASI SISTEM PENGENDALIAN INTERN (INTERNAL CONTROL) TERHADAP KINERJA DINAS PEKERJAAN UMUM PROVINSI SULAWESI UTARA
}

\author{
Julia Christina Turangan ${ }^{1}$, David P. E. Saerang ${ }^{2}$, Rudy J. Pusung ${ }^{3}$ \\ ${ }^{1,2,3}$ Fakultas Ekonomi dan Bisnis. Jurusan Akuntansi. Universitas Sam Ratulangi, Jl. Kampus Bahu, Manado, \\ 95115, Indonesia
}

Email : jcturangan27@gmail.com

\begin{abstract}
Implementation of internal control system is needed so that activities can be implemented effectively and efficiently, and generate a reliable reports. As one of the public sector organization, Dinas Pekerjaan Umum Provinsi Sulawesi Utara also requires internal control for the effectiveness and efficiency of their activities and produce a reliable reporting to reduce abuse of authority from irresponsible parties. The purpose of this research is to evaluate the system of internal control on performance of Dinas Pekerjaan Umum Provinsi Sulawesi Utara. The method that used in this research is qualitative research methods with data analisys technique is data reduction, presentation of data, and conclusions. The results of this study are internal controls applied by Dinas Pekerjaan Umum Provinsi Sulawesi Utara has been effective and adequate. Realization of expenditure Dinas Pekerjaan Umum Provinsi Sulawesi Utara from 2013 to 2015 has been effective.
\end{abstract}

Keywords : Evaluation, Internal control, Performance

\section{PENDAHULUAN}

Di era globalisasi dewasa ini, pembangunan nasional merupakan salah satu hal yang penting karena peningkatan pembangunan nasional dapat meningkatkan seluruh aspek kehidupan masyarakat, bangsa dan negara yang juga merupakan proses pengembangan keseluruhan sistem penyelenggaraan Negara untuk tujuan nasional. Pembangunan ekonomi yang selama ini telah menghasilkan pertumbuhan yang tinggi ternyata belum sepenuhnya dapat mengatasi masalah kesenjangan antar daerah di Indonesia. Perbedaan laju pembangunan antar daerah menyebabkan terjadinya kesenjangan kemakmuran dan kemajuan antar daerah, terutama antara jawa dan luar jawa, antara kawasan Barat dan kawasan Timur, antara pedesaan dan perkotaan. Sehubungan dengan itu pemerintah memberlakukan otonomi daerah dalam pelaksanaan pemerintahannya.

Dengan diberlakukannya otonomi daerah, daerah memiliki hak untuk mengatur daerahnya sendiri namun tetap dikontrol oleh pemerintah pusat dan Undang-Undang. Dalam konteks otonomi daerah, desentralisasi dimaksudkan agar daerah lebih mampu mengembangkan inisiatif dan kreativitas daerah dan sumberdayanya untuk mendorong pertumbuhan ekonomi, meningkatkan pelayanan kepada masyarakat dan meningkatkan pemberdayaan masyarakat. Penyelenggaraan otonomi daerah dilaksanakan dengan memberikan kewenangan luas, nyata dan bertanggung jawab kepada daerah secara proporsional yang diwujudkan dengan pengaturan, pembagian, dan pemanfaatan sumberdaya nasional yang berkeadilan serta perimbangan keuangan antara pemerintah pusat dan derah. Namun kesemuanya itu perlu diimbangi dengan sistem pengawasan yang memadai agar tidak menimbulkan Korupsi, Kolusi dan Nepotisme (KKN) baru.

Dalam rangka pelaksanaan pekerjaan dan untuk mencapai tujuan dari pemerintah yang telah direncanakan maka perlu ada pengawasan, karena dengan pengawasan tersebut, maka tujuan yang akan dicapai dapat dilihat dengan berpedoman pada rencana yang telah ditetapkan terlebih dahulu oleh pemerintah. Dengan demikian pengawasan itu sangat penting 
dalam melaksanakan pekerjaan dan tugas pemerintah, sehingga pengawasan di adakan dengan maksud untuk mengetahui jalan pekerjaan apakah lancar atau tidak untuk memperbaiki kesalahan-kesalahan yang dibuat oleh pegawai dan mengadakan pencegahan agar tidak terulang kembali kesalahan-kesalahan yang sama atau timbulnya kesalahan yang baru dan juga mengetahui pelaksanaan kerja sesuai dengan program seperti yang telah ditentukan dalam planning atau tidak.

Dengan diberlakukannya UU No. 17 tahun 2003 tentang Keuangan Negara dan UU Nomor 1 tahun 2004 tentang Perbendaharaan Negara serta peraturan pendukungnya, Menteri/pimpinan lembaga selaku pengguna anggaran/pengguna barang wajib menyelenggarakan Sistem Pengendalian Intern dibidang pemerintahan masing-masing. Oleh karena itu, setiap entitas dalam pelaporan akuntansi keuangan negara wajib menyelenggarakan sistem pengendalian intern sesuai dengan peraturan perundang-undangan yang terkait untuk meningkatkan keandalan laporan keuangan dan kinerja. Penerapan sistem pengendalian intern dibutuhkan agar kegiatan dapat dilaksanakan dengan efektif dan efisien, serta menghasilkan pelaporan yang andal dan adanya ketaatan terhadap peraturan perundangundangan. Karena jika sistem pengendalian internal yang diterapkan di masing-masing organisasi sektor publik masih lemah, penyalahgunaan wewenang akan dengan begitu mudahnya dilakukan.

Sebagai salah satu organisasi sektor publik, Dinas Pekerjaan Umum Provinsi Sulawesi Utara juga membutuhkan pengendalan intern guna keefektifan dan keefisienan kegiatan mereka serta menghasilkan pelaporan keuangan yang andal demi mengurangi penyalahgunaan wewenang dari pihak-pihak yang tidak bertanggung jawab seperti orang yang melanggar tugas dan wewenang perusahaan. Untuk itulah mengapa pengendalian intern sangat penting diterapkan secara benar oleh masing-masing organisasi. Berdasarkan PP Nomor 60 tahun 2008 Sistem Pengendalian Intern adalah proses yang integral pada tindakan dan kegiatan yang dilakukan secara terus menerus oleh pimpinan dan seluruh pegawai untuk memberikan keyakinan memadai atas tercapainya tujuan organisasi melalui kegiatanyang efektif dan efisien, keandalan pelaporan keuangan, pengamanan aset negara, dan ketaatan terhadap peraturan perundang-undangan. Untuk mencapai pengelolaan keuangan yang efektif, efisien, transparan, dan akuntabel, menteri/pimpinan lembaga, gubernur dan bupati/walikota wajib melakukan pengendalian atas penyelenggaraan kegiatan pemerintah dan berpedoman pada SPIP berdasarkan PP Nomor 60 tahun 2008. Di Dinas Pekerjaan Umum provinsi Sulawesi Utara sangatlah penting jika pengendalian intern terhadap pelaporan keuangan dapat dilaksanakan secara efektif oleh pihak berwajib guna meminimalisir hal-hal yang dapat merugikan Negara, karena anggaran yang digunakan adalah anggaran dari negara yang berhak dikontrol secara baik penggunaanya dilihat dari hasil pelaporan keuangan oleh yang berwenang mengurus hal itu.

\section{TINJAUAN PUSTAKA}

\subsection{Konsep Akuntansi}

Definisi resmi yang mula-mula diajukan adalah definisi yang dimuat dalam Accounting Terminology Bulletin No.1 yang diterbitkan oleh Accounting Principles Board (APB) yaitu suatu komite penyusunan prinsip akuntansi yang dibentuk oleh American Institute of Certified Public Accountants (AICPA). Komite tersebut mendefinisikan akuntansi sebagai berikut:

Accounting is the art of recording, classifying, and summerizing in a significant manner and in terms of money, transactions and events which are, in part at least, of financial character, and interpreting the results thereof.

Akuntansi adalah seni pencatatan, penggolongan dan peringkasan transaksi dan kejadian yang bersifat keuangan dengan cara yang berdaya guna dan dalam 
bentuk satuan uang, dan penginterpretasian hasil proses tersebut. (Suwardjono, 2014:5)

Penyelenggaraan akuntansi mengiringi reformasi dalam bidang politik yang diungkapkan dalam peraturan pelaksanaan otonomi daerah. Ini tertuang dalam Undang-undang nomor 22/1999, yang diikuti dengan undang-undang nomor 25/1999 tentang peraturan hubungan keuangan antara pemerintah pusat dan daerah. Juga diikuti dengan peraturan pemerintah (PP) nomor 105/2000 tentang pengelolaan keuangan daerah. (Mursyidi, 2013:8)

\subsection{Pengendalian Internal}

Pengendalian internal adalah seperangkat kebijakan dan prosedur untuk melindungi aset atau kekayaan perusahaan dari segala bentuk tindakan penyalahgunaan, menjamin tersedianya informasi akuntansi perusahaan yang akurat, serta memastikan bahwa semua ketentuan (peraturan) hukum/undang-undang serta kebijakan manajemen telah dipatuhi atau dijalankan sebagaimana mestinya oleh seluruh karyawan perusahaan.

Dengan adanya penerapan sistem pengendalian internal secara ketat maka diharapkan bahwa seluruh kegiatan operasional perusahaan dapat berjalan dengan baik menuju tercapainya maksimalisasi profit. Bahkan tidak hanya dari segi operasional saja yang akan berjalan dengan tertib dan baik sesuai prosedur, akan tetapi dari segi finansial perusahaan juga dapat lebih termonitor dengan baik.

Pada dasarnya, faktor efisiensi dan efektivitas unit/perusahaan merupakan dua hal yang juga merupakan sasaran dari diterapkannya pengendalian internal, karena kalau pengendalian internal tidak berjalan sebagaimana yang diharapkan, maka kemungkinan besar (hampir dapat dipastikan) akan timbul yang namanya inefisiensi (pemborosan sumber daya), yang pada akhirnya tentu saja hal ini hanya akan membebani tingkat profitabilitas (keuntungan) perusahaan. (Hery, 2014:189)

\subsection{Pengertian Kinerja}

Kinerja (performance) adalah kuantitas dan atau kualitas hasil kerja individu atau sekelompok didalam organisasi dalam melaksanakan tugas pokok dan fungsi yang berpedoman pada norma, standar operasional prosedur, kriteria dan ukuran yang telah ditetapkan atau yang berlaku dalam organisasi.

Kinerja menurut Mc Clelland (1967) menentukan beberapa karakteristik kinerja, yaitu: bertanggung jawab dalam pemecahan masalah, menetapkan tujuan, ada umpan balik dan dapat diandalkan.

Robbins (2003) berpendapat bahwa kinerja menghadirkan fungsi dan kemempuan (ability), motivasi (motivation), dan kesempatan (opportunity) dalam. Dengan demikian kinerja ditentukan atau dipengaruhi oleh faktor-faktor kemampuan, motivasi, dan kesempatan. (Torang, 2013:76)

\section{METODE PENELITIAN}

\subsection{Jenis dan sumber data}

Metode penelitian kualitatif adalah metode penelitian yang berlandaskan pada filsafat postpositivisme, digunakan untuk meneliti pada kondisi obyek ilmiah, (sebagai lawannya adalah eksperimen) dimana peneliti adalah sebagai instrument kunci, teknik pengumpulan data dilakukan secara triangulasi (gabungan), analisis data bersifat induktif/kuantitatif, dan hasil penelitian kualitatif lebih menekankan makna daripada generalisasi. (Sugiyono, 2014:9).. Dalam penelitian ini, penelti menggunakan metode penelitian kualitatif, dengan mengambil data pada Dinas Pekerjaan Umum Provinsi Sulawesi Utara. 


\subsection{Metode Pengumpulan Data}

Teknik pengumpulan data merupakan langkah yang paling strategis dalam penelitian, karena tujuan utama dari penelitian adalah mendapatkan data. Tanpa mengetahui teknik pengumpulan data, maka peneliti tidak akan mendapatkan data yang memenuhi standar data yang ditetapkan. (Sugiyono, 2014: 224).

1. Pengumpulan data primer

Sumber primer adalah sumber data yang langsung memberikan data kepada pengumpul data.

2. Pengumpulan data sekunder

Sumber sekunder merupakan sumber yang tidak langsung memberikan data kepada pengumpul data, misalnya lewat orang lain atau lewat dokumen. (Sugiyono, 2014: 225)

Data yang di maksud dikumpulkan dengan teknik sebagai berikut:

a. Wawancara/interview: teknik ini digunakan untuk menjaring data primer yaitu dengan melakukan Tanya jawab langsung dengan respounden / informan dengan berpedoman dengan daftar pertanyaan yang di sampaikan lebih dulu.

b. Observasi : yaitu dengan melakukan pengamatan secara langsung terhadap gejala atau fenomena yang di teliti. Teknik ini digunakan untuk memperdalam data yang diperoleh melalui wawancara.

c. Studi dokumentasi : yang digunakan untuk memperoleh data sekunder yang berhubungan dengan objek yang di teliti dengan cara mengumpulkan,mengklasifikasi dan mempelajari data - data yang telah tersedia pada unsur terkait.

\subsection{Metode analisis}

Penelitian ini merupakan penelitian kualitatif, maka sesuai dengan penelitian ini teknik analisis data ialah analisis deskriptif kualitatif.

Langkah-langkah dalam analisis data yaitu sebagai berikut:

1. Reduksi data, mereduksi data berarti merangkum, memilih hak-hak pokok yang penting, dicari tema dan polanya. Dengan demikian data data yang telah direduksi akan memberikan gambaran yang lebih jelas dan mempermudah peneliti untuk melakukan pengumpulan data selanjutnya, dan mencari bila diperlukan.

2. Penyajian data. Penyajian data ini dilakukan dalam bentuk uraian singkat, bagan, hubungan antara kategori, flowchart dan sejenisnya, atau dilakukan penyajian data dengan teks yang bersifat naratif.

3. Penarikan kesimpulan dan verifikasi, kesimpulan dalam penelitian kualitatif adalah merupakan temuan baru yang sebelumnya belum pernah ada. Temuan dapat berupa deskripsi data gambaran suatu objek yang sebelumnya masih remang - remang atau gelap sehingga setelah diteliti menjadi jelas, dapat berupa hubungan kausal atau interaktif, hipotesis atau teori. (Sugiyono, 2014: 245-253)

\section{HASIL ANALISIS DAN PEMBAHASAN}

\subsection{Hasil analisis}

\section{A. Sistem Pengendalian Internal pada Dinas Pekerjaan Umum Sulawesi Utara}

1) Lingkungan Pengendalian

Ada beberapa unsur yang diterapkan dinas Pekerjaan Umum tentang lingkungan pengendalian, antara lain:

a. Integritas dan nilai etika

Integritas dan nilai etika diterapkan dengan baik oleh dinas Pekerjaan umum pada seluruh pegawainya. Dalam struktur SPI dinas pekerjaan umum sudah mencakup kerangka kerja perencanaan, pelaksanaan, pengendalian, dan pengawasan dalam 
mencapai tujuan pengendalian internal. Dinas Pekerjaan Umum juga selalu memberikan arahan kepada para pegawai maupun para pengelola keuangan agar bekerja sesuai aturan yang ada sehingga struktur organisasi secara umum maupun di bagian keuangan telah memadai. Juga bagi para pegawai, dinas Pekerjaan Umum dilakukan pengembangan sumber daya dari para personel dengan program diklat dan bimbingan teknis di bidang masing-masing. Dengan demikian setiap bagian mengetahui bagian tugas dan kerja masing-masing. Jika masih terdapat pegawai yang melanggar atran yang telah ditetapkan, makadinas Pekerjaan Umum akan memberikan sanksi antara lain teguran lisan maupun tulisan kepada pegawai yang diangggap melanggar aturan atau belum melaksanakan aturan dengan baik.

Dengan demikian, dan hal itu dapat menekan penyimpangan yang terjadi dalam dinas Pekerjaan Umum provinsi Sulawesi Utara.

b. Komitmen terhadap kompetensi

Komitmen terhadap Kompetensi dinas Pekerjaan Umum sudah cukup baik diterapkan. Para pegawai ditempatkan sesuai bidang pendidikan, pengetahuan maupun keahlian masing-masing. Dan seperti yang telah dijelaskan pada poin a, dinas pekerjaan umum melakukan pengembangan sumber daya manusianya lewat diklat dan bimbingan teknis.

c. Dewan direksi dan Komite Audit

Berkaitan dengan satuan pengendalian intern dinas pekerjaan umum, terdapat tenaga ahli yang berasal dari Inspektorat provinsi yang memiliki peran dalam pengendalian internal yaitu untuk membantu seluruh pelaksana di dinas agar dapat bekerja sesuai atran yang berlaku dan mencegah terjadinya kesalahan yang dapat mengakibatkan kerugian negara.

Objektivitas dijunjung tinggi dalam pekerjaan khususnya dalam pengelolaan keuangan. Aktivitas dinas pekerjaan umum yang memberikan pelayanan publik pada masyarakat lewat pembangunan infrastruktur juga telah dijalankan dengan baik dan dinamis, juga telah bekerja sesuai dengan prinsip korporasi yang sehat dan tidak terpengaruh dengan puhak luar.

d. Filosofi dan gaya Operasi

Bila melihat gaya operasi dalam dinas pekerjaan umum, telah ada pemisahan fungsi tugas kerja yang jelas, sehingga para pegawai bekerja dan ditempatkan sesuai dengan bagian yang dikuasai dengan melihat latar belakang pendidikan dan keahlian masingmasing.

e. Struktur Organisasi

Struktur organisasi Dinas Pekerjaan Umum menyesuaikan dengan ukuran dan sifat organisasi.Pimpinan-pimpinan di setiap bagian yang ada memahami tugas dan tanggung jawabnya dan memastikan juga bahwa pegawainya memahami tugas dan tanggung jawab masing-masing. Komunikasi yang tercipta antara atasan dan bawahan juga baik, sehingga pencapaian tujuan organisasi dapat dengan mudah dicapai.

f. Pembagian Wewenang dan Tanggung Jawab

Wewenang dalam Dinas Pekerjaan Umum diberikan kepada pegawai yang tepat sesuai dengan tingkat tanggung jawab dan dikomunikasikan kepada seluruh pegawai guna dilaksanakan demi pencapaian tujuan Dinas Pekerjaan Umum. Para pegawai juga diarahkan untuk mengatasi masalah maupun memperbaiki jika masalah sudah terlanjur terjadi dalam lingkungan Dinas Pekerjaan Umum.

g. Kebijakan dan Praktik

Dinas Pekerjaan Umum menetapkan kriteria yang jelas tentang standar pegawai dengan penekanan pada pendidikan, pengalaman, prestasi maupun etika pegawai.Juga terdapat program pelatihan yang berkesinambungan bagi sumber daya manusia yang 
ada dalam lingkungan Dinas Pekerjaan Umum. Integritas dan etika juga merupakan faktor penting yang menjadi pertimbangan bagi para pegawainya. Untuk itu ketika pegawai melanggarintegritas dan etika yang ada maka pegawai yang menyalahi aturan tersebutakan mendapat teguran maupun sanksi yang tegas.

2) Penilaian Risiko

Penilaian Risiko sangat penting dilakukan oleh pimpinan instansi pemerintah dalam hal ini pimpinan Dinas Pekerjaan Umum Provinsi Sulawesi Utara. Berdasarkan PP No.60 Tahun 2008 tentang Sistem Pengendalian Intern Pemerintah, penilaian risiko terdiri atas (a) identifikasi risiko dan (b) analisis risiko. Dalam rangka penilaian risiko, pimpinan instansi pemerintah menetapkan tujuan dinas pekerjaan umum, serta tujuan pada tingkatan kegiatan dengan berpedoman pada peraturan perundang-undangan dan kemudian dikomunikasikan pada seluruh staf pegawai. Untuk mencapai tujuan itu, pimpinan dinas menetapkan strategi operasional serta strategi menajemen dan penilaian risiko. Setelah mengenali risiko dari faktor internal dan eksternal dan menilai faktor lain yang dapat meningkatkan risiko, pimpinan menerapkan prinsip kehati-hatian dalam menentukan tingkat risiko.

3) Aktifitas Pengendalian

Sebagaimana dijelaskan dalam Peraturan Pemerintah Nomor 60 Tahun 2008 tentang Sistem Pengendalian Intern Pemerintah bahwa pimpinan Instansi pemerintah wajib menyelenggarakan kegiatan pengendalian sesuai dengan ukuran, kompleksitas, dan sifat dari tugas dan fungsi Instansi Pemerintah yang bersangkutan, maka dinas Pekerjaan Umum melakukan beberapa poin kegiatan pengendalian, antara lain:

a. Pemisahan Tugas Yang Cukup

Berdasarkan struktur oraganisasi Dinas Pekerjaan Umum, dapat kita lihat bahwa Dinas Pekerjaan Umum membagi beberapa bagian bidang fungsi yang berbeda yaitu:

1. Bidang Bina Marga

2. Bidang Cipta Karya

3. Bidang Sumber daya Air

4. Bidang Tata Ruang

5. UPTD Balai Pengujian Mutu Konstruksi

6. UPTD Balai Peralatan dan Perbekalan

7. UPTD Balai Bina Teknik

8. UPTD Air Minum

9. UPTD Wilayah I

10. UPTD Wilayah II

11. UPTD Wilayah III

12. UPTD Wiayah IV

Dalam penyusunan laporan keuangan pun, terdapat Bendahara penerimaan dan bendahara pengeuaran, dimana kas di bendahara penerimaan mencakup seluruh kas, baik saldo rekening di bank dan uang tunai, yang berada di bawah tanggung jawab bendahara penerimaan.Kas tersebut berasal dari pungutan yang sudah diterima oleh bendahara penerimaan, yang beum disetor ke Kas Daerah.Dan kas di bendahara Pengeluaran adalah kas yang masih dikelola Bendahara Pengeluaran SKPD yang berasal dari sisa uang muka kerja yang belum disetor ke kas daerah per tanggal neraca. Kas di bendahara pengeluaran mencakup seluruh saldo rekening Bendahara Pengeluaran, uang logam, uang kertas, dan lain-lain kas yang benar-benar adapada Bendahara Pengeluaran per tanggal neraca.

b. Reviu Atas Kinerja

Guna pencapaian visi dan misi Dinas, tentunya ada yang menjadi tolok ukur penialaian, itulah yang dijadikan pedoman atasan dalam mereviu kinerja pegawainya 
agar dapat memberikan kinerja yang terbaik dalam pelaksanaan tugas para pegawainya.

c. Pembinaan Sumber Daya Manusia

Pembinaan Sumber daya manusia dilakukan dinas Pekerjaan Umum demi terciptanya lingkungan kerja yang baik. Setelah penetapan tujuan Dinas, dan mengkomunikasikan kepada seluruh pegawai, Dinas Pekerjaan Umum melakukan pembinaan sumber daya manusia agar mendukung pencapaian tujuan Instansi.

d. Pengendalian Atas Pengelolaan Sistem Informasi

Pengendalian atas pengelolaan sistem informasi ini dilakukan untuk memastikan akurasi dan kelengkapan sistem informasi suatu organisasi maupun Instansi pemerintah. Untuk itu Dinas Pekerjaan Umum berkenaan dengan pengelolaan keuangan dinas melakukan otorisasi atas transaksi keluar masuk uang dan kejadian penting berdasarkan aturan yang berlaku. Pecatatan dilakukan secara akurat dan tepat waktu dalam satu dokumen.

Dinas pekerjaan Umum juga transparan dalam penggunaan anggaran, hal itu dibuktikan dengan memberikan informasi keuangan yang jujur dan laporan yang akurat dan dapat diakses oleh siapa saja yang berkepentingan sesuai dengan aturan yang berlaku.

Laporan Keuangan mengacu pada Standar Akuntansi Pemerintah (PP 71 Tahun 2010) namun dalam penyajiannya berdasarkan Permendagri No. 13 Tahun 2006. Hal ini bertujuan agar pihak-pihak yang berkepentingan dapat memahami terutama dalam rangka memperbandingkan antara realisasi dengan anggaran yang telah ditetapkan.

4) Informasi dan Komunikasi

Dalam Dinas Pekerjaan Umum, informasi tentang tujuan instansi dikomunikasikan dengan jelas kepada seluruh pegawai tentang apa yang harus dilakukan agar keseluruhan tujuan dapat dicapai dengan baik.

Informasi disediakan tepat waktu agar dapat dilaksanakan pemantauan sehingga bila diperlukan tindakan koreksi dapat dilakukan secara cepat.

5) Pemantauan

Pemantauan dilakukan dengan tujuan jika terjadi kesalahan, dapat dideteksi secara dini dan dilakukan tindak pencegahan yang tepat. Di Dinas Pekerjaan Umum, pemantauan dilakukan secara berkala baik oleh pengawas internal maupun eksternal. Juga dilakukan eveluasi secara berkala segala kegiatan pengendalian atas operasi yang mendukung pencapaian tujuan organisasi.

B. Target dan Realisasi Anggaran Belanja Dinas Pekerjaan Umum Provinsi Sulawesi Utara

Demi terciptanya keefektifan dan keefisienan kinerja, Dinas Pekerjaan Umum telah menyusun target anggaran yang akan diperoleh dan yang telah direalisasi atau yang telah dicapai dari tahun 2013 sampai tahun 2015. 
Tabel 4.1 Anggaran dan Realisasi Belanja Tahun 2013

\begin{tabular}{|l|r|r|}
\hline \multicolumn{1}{|c|}{ Uraian } & \multicolumn{1}{c|}{ Anggaran } & \multicolumn{1}{c|}{ Realisasi } \\
\hline BELANJA OPERASI & $\mathbf{2 2 5 , 7 0 8 , 4 3 7 , 8 6 2 . 0 0}$ & $\mathbf{2 0 4 . 9 1 9 . 6 3 1 . 2 2 4 , 0 0}$ \\
\hline Belanja Pegawai & $32.291 .603 .794,00$ & $31.924 .607 .813,00$ \\
\hline Belanja Barang & $193.416 .834,068,00$ & $172.995 .023 .411,00$ \\
\hline BELANJA MODAL & $\mathbf{2 3 0 . 7 9 2 . 8 7 6 . 4 3 8 , 0 0}$ & $\mathbf{2 0 6 . 8 8 7 . 8 0 3 . 8 9 0 , 0 0}$ \\
\hline Belanja tanah & $100.475 .401 .824,00$ & $96.292 .790 .603,00$ \\
\hline Belanja Peralatan dan Mesin & $8.155 .321 .814,00$ & $5.155 .291 .425,00$ \\
\hline Belanja Bangunan dan Gedung & $1.707 .402 .000,00$ & $1.416 .695 .794,00$ \\
\hline Belanja Jalan, Irigasi, dan Jaringan & $120.344 .750 .800,00$ & $103.911 .321 .068,00$ \\
\hline Belanja Aset Tetap Lainnya & $110.000 .000,00$ & $111.705 .000,00$ \\
\hline TOTAL & $\mathbf{4 5 6 , 5 0 1 , 3 1 4 . 3 0 0 . 0 0}$ & $\mathbf{4 1 1 . 8 0 7 . 4 3 5 . 1 1 4 . 0 0}$ \\
\hline
\end{tabular}

Tabel 4.2 Anggaran dan Realisasi Belanja Tahun 2014

\begin{tabular}{|l|r|r|}
\hline \multicolumn{1}{|c|}{ Uraian } & \multicolumn{1}{c|}{ Anggaran } & \multicolumn{1}{c|}{ Realisasi } \\
\hline BELANJA OPERASI & $\mathbf{1 0 1 . 4 5 9 . 1 0 0 . 6 9 7 , 6 5}$ & $\mathbf{8 6 . 0 8 8 . 0 4 4 . 8 2 7 , 0 0}$ \\
\hline Belanja Pegawai & $30.624 .879 .000,00$ & $30.239 .281 .466,00$ \\
\hline Belanja Barang & $70.834 .221 .697,65$ & $55.848 .763 .361,00$ \\
\hline BELANJA MODAL & $\mathbf{3 1 1 . 9 1 5 . 2 1 4 . 4 8 0 , 8 4}$ & $\mathbf{2 5 5 . 4 9 9 . 3 1 4 . 1 1 0 , 0 0}$ \\
\hline Belanja Tanah & $64.196 .293 .930,00$ & $59.657 .340 .504,00$ \\
\hline Belanja Peralatan dan Mesin & $7.485 .262 .000,00$ & $6.009 .939 .000,00$ \\
\hline Belanja Bangunan dan Gedung & $3.814 .255 .900,00$ & $3.078 .067 .600,00$ \\
\hline Belanja Jalan, Irigasi, dan Jaringan & $236.344 .402 .650,84$ & $186.694 .067 .006,00$ \\
\hline Belanja Aset Tetap Lainnya & $75.000 .000,00$ & $59.900 .000,00$ \\
\hline TOTAL & $\mathbf{4 1 3 . 3 7 4 . 3 1 5 . 1 7 8 , 4 9}$ & $\mathbf{3 4 1 . 5 8 7 . 3 5 8 . 9 3 7 , 0 0}$ \\
\hline
\end{tabular}

Tabel 4.3 Anggaran dan Realisasi Belanja Tahun 2015

\begin{tabular}{|l|r|r|}
\hline \multicolumn{1}{|c|}{ Uraian } & \multicolumn{1}{|c|}{ Anggaran } & \multicolumn{1}{c|}{ Realisasi } \\
\hline Belanja Operasi & $\mathbf{9 7 . 9 5 4 . 0 6 6 . 1 0 2 , 0 0}$ & $\mathbf{8 7 . 4 0 7 . 7 0 5 . 7 8 4 , 0 0}$ \\
\hline Belanja Pegawai & $31.257 .719 .929,00$ & $30.939 .402 .592,00$ \\
& & \\
\hline Belanja Barang Dan Jasa & $66.696 .346 .173,00$ & $56.468 .303 .192,00$ \\
\hline Belanja Subsidi & 0,00 & 0,00 \\
\hline Belanja Hibah & 0,00 & 0,00 \\
\hline Belanja Bantuan Sosial & 0,00 & 0,00 \\
\hline Belanja Modal & $\mathbf{5 2 0 . 0 2 8 . 3 5 2 . 0 4 4 , 0 0}$ & $\mathbf{5 1 0 . 6 4 2 . 9 9 9 . 7 8 9 , 0 0}$ \\
\hline Belanja Tanah & $20.505 .797 .723,00$ & $19.963 .414 .734,00$ \\
\hline Belanja Peralatan dan Mesin & $8.654 .642 .650,00$ & $8.368 .506 .707,00$ \\
\hline Belanja Bangunan dan Gedung & $8.334 .977 .575,00$ & $5.449 .975 .055,00$ \\
\hline Belanja Jalan, Irigasi, dan Jaringan & $482.385 .434 .096,00$ & $476.816 .103 .293,00$ \\
\hline Belanja Aset Tetap Lainnya & $147.500 .000,00$ & $45.000 .000,00$ \\
\hline Belanja Tak Terduga & $\mathbf{0 , 0 0}$ & $\mathbf{0 , 0 0}$ \\
\hline Belanja Tak Terduga & 0,00 & 0,00 \\
\hline TOTAL & $\mathbf{6 1 7 . 9 8 2 . 4 1 8 . 1 4 6 , 0 0}$ & $\mathbf{5 9 8 . 0 5 0 . 7 0 5 . 5 7 3 , 0 0}$ \\
\hline
\end{tabular}




\subsection{Pembahasan}

Pengendalian Internal Terhadap Kinerja Dinas Pekerjaan Umum Provinsi Sulawesi Utara

1. Lingkungan Pengendalian

Pengendalian Intenal yang diterapkan Dinas Pekerjaan Umum sudah dijalankan dengan baik. Para pimpinan dan para pegawai menjunjung tinggi integritas dan nilai etika, hal ini dibuktikan dengan adanya sanksi bagi pegawai yang melanggar aturan yang ditetapkan dengan cara mendapat teguran lisan maupun tulisan. Hal tersebut dapat menekan terjadinya penyimpangan di Dinas Pekerjaan Umum. Para pegawai juga ditempatkan sesuai dengan bidang dan keahlian masing-masing juga dilakukan pengembangan sumber daya manusia seperti diklat dan pelatihan demi menunjang kinerja pegawai. Pemisahan fungsi tugas kerja juga jelas sehingga para pegawai bekerja dan ditempatkan di bagian yang sesuai dengan latar belakang pengalaman dan pendidikannya. Komunikasi yang tercipta antara bawahan dan atasan juga baik sehingga tercipta lingkungan yang kondusif dan mempermudah dalam pencapaian tujuan dinas. Pembambagian wewenang dan tanggung jawab juga dikomunikasikan dengan baik oleh pimpinan kepada bawahan sehingga para pegawai diarahkan untuk mengatasi masalah maupun memperbaiki masalah yang sudah terlanjur terjadi. Dinas Pekerjaan Umum juga menetapkan berbagai kriteria yang jelas sehubungan dengan penerimaan karyawan baru serta mengadakan pelatihan secara berkesinambungan.

Dengan demikian dapat dikatakan lingkungan pengendalian memiliki peranan penting dalam menunjang kinerja para pegawai Dinas Pekerjaan Umum Provinsi Sulawesi Utara.

2. Penilaian Risiko

Dalam rangka penilaian risiko, pimpinan instansi pemerintah menetapkan tujuan istansi pemerintah dan tujuan pada tingkat kegiatan dengan berpedoman pada peraturan perundang-undangan dan dikomunikasikan kepada seluruh pegawai.

Untuk menyiasati hal itu, penetapan tujuan dinas Pekerjaan Umum juga didalamnya ada bagian keuangan dilakukan bersama agar sesuai dan mencapai sasaran yang diinginkan.

Tujuan dan rencana strategi pemerintah dikomunikasikan kepada seluruh pegawai agar pada penerapannya didukung oleh sumber daya yang cukup dan melibatkan seluruh tingkat pejabat yang ada.

Analisis risiko dilakukan dengan mekanisme yang memadai untuk mengenali risiko maupun faktor-faktor lain yang dapat meningkatkan risiko, sehingga penerapan faktor-faktor risiko dilakukan agar terhindar dari kesalahan yang mungkin terjadi dalam pengelolaan keuangan maupun dalam pencapaian tujuan Dinas Pekerjaan Umum secara menyeluruh.

Dari penjelasan diatas dapat dinilai bahwa penilaian risiko telah dilaksanakan dengan baik oleh Dinas Pekerjaan Umum

3. Kegiatan Pengendalian

Kegiatan pengendalian sangat penting untuk meyakinkan bahwa tindakan yang diperlukan dalam mencapai tujuan dinas dan menghadapi risiko telah dilaksanakan dengan baik. Kegiatan pengendalian terhadap kinerja Dinas Pekerjaan Umum telah berjalan dengan baik. Hal ini dibuktikan dengan adanya pembagian 12 bidang fungsi yang berbeda. Dalam proses penyusunan laporan keuangannya pun terdapat bendahara penerimaan dan bendahara pengeluaran yang berbeda demi meminimalisir kecurangan yang dapat terjadi. Kinerja para pegawainya juga dinilai secara berkala demi mencapai visi dan misi dinas. Pembinaan sumber daya manusia juga dilakukan secara berkala dan dilakukan pengendalian pengelolaan sistem informasi. 


\section{Informasi dan Komunikasi}

Informasi dan komunikasi yang diterapkan dinas telah dilaksanakan dengan baik dimana informasi tentang tujuan dinas dikomunikasikan dengan baik dari atasan hinga bawahannya sehingga informasi yang dibutuhkan tersedia tepat waktu aga dapat dilaksanakan pemantauan maupun kegiatan pencegahan dari risiko yang dapat ditimbulkan dari kinerja para karyawan.

\section{Pemantauan}

Pengawasan atau pemantauan memiliki peran yang penting dalam menunjang kinerja dinas. Para pemimpin dinas sangat menyadari hal itu, maka dilakukanlah pemantauan secara rutin dan berkelanjutan sehingga kesalahan dapat dideteksi sejak dini sehingga apabila terjadi kesalahan dapat segera dilakukan tindakan pencegahan.

Oleh karena itu dapat disimpulkan bahwa kegiatan pemantauan Dinas Pekerjaan Umum telah dilaksanakan dengan baik.

B. Tabel Perbandingan Unsur Sistem Pengendalian Intern Pemerintah berdasarkan Peraturan Pemerintah Republik Indonesia Nomor 60 Tahun 2008 dengan Sistem

Pengendalian Intern Dinas Pekerjaan Umum Provinsi Sulawesi Utara.

Tabel 4.4 Tabel Perbandingan Unsur Sistem Pengendalian Intern

\begin{tabular}{|c|c|c|c|}
\hline No. & \multicolumn{2}{|r|}{ PP No. 60 Tahun 2008} & Dinas Pekerjaan Umum \\
\hline 1. & $\begin{array}{l}\text { Lingkungan } \\
\text { Pengendalian }\end{array}$ & & \\
\hline a. & $\begin{array}{l}\text { Penegakan } \\
\text { Integritas dan } \\
\text { Nilai Etika }\end{array}$ & $\begin{array}{l}\text { Menyusun dan menerapkan aturan } \\
\text { perilaku, } \\
\text { Memberikan keteladanan } \\
\text { pelaksanaan aturan, } \\
\text { - } \text { Menegakkan tindakan disiplin, } \\
\text { Menjelaskan dan } \\
\text { mempertanggungjawabkan adanya } \\
\text { intervensi atau pengabaian } \\
\text { pengendalian intern, } \\
\text { Menghapus kebijakan yg mendorong } \\
\text { perilaku tidak etis. }\end{array}$ & $\begin{array}{l}\text { Sudah baik, Dinas } \\
\text { Pekerjaan Umum telah } \\
\text { menyusun dan } \\
\text { menerapkan aturan } \\
\text { perilaku, memberikan } \\
\text { teladan, dan menegakkan } \\
\text { tindakan disiplin bagi } \\
\text { karyawan yang } \\
\text { melanggar aturan. }\end{array}$ \\
\hline b. & $\begin{array}{l}\text { Komitmen } \\
\text { terhadap } \\
\text { kompetensi }\end{array}$ & $\begin{array}{l}\text { Mengidentifikasi dan menetapkan } \\
\text { kegiatan yang dibutuhkan untuk } \\
\text { menyelesaikan tugas dan fungsi } \\
\text { masing-masing posisi, } \\
\text { - Menyusun standar kompetensi untuk } \\
\text { setiap tugas dan fungsi, } \\
\text { Menyelenggarakan pelatihan dan } \\
\text { pembimbingan, } \\
\text { Memilih pimpinan yang memiliki } \\
\text { kemampuan dan pengalaman teknis } \\
\text { yang luas. }\end{array}$ & $\begin{array}{l}\text { Sudah baik, para pegawai } \\
\text { ditempatkan sesuai } \\
\text { bidang pendidikan } \\
\text { maupun keahlian masing- } \\
\text { masing, dan Dinas } \\
\text { Pekerjaan Umum juga } \\
\text { menyelenggarakan } \\
\text { bimbingan dan pelatihan } \\
\text { bagi sumber daya } \\
\text { manusianya. }\end{array}$ \\
\hline c. & $\begin{array}{l}\text { Kepemimpinan } \\
\text { yang kondusif. }\end{array}$ & $\begin{array}{l}\text { Mempertimbangkan risiko dalam } \\
\text { pengambilan keputusan } \\
\text { - Menerapkan manajemen berbasis } \\
\text { kinerja, } \\
\text { Mendukung fungsi tertentu dalam } \\
\text { penerapan SPIP, } \\
\text { Melindungi aset dan informasi dari } \\
\text { akses yang tidak sah, } \\
\text { Melakukan interaksi dengan pejabat } \\
\text { pada tingkatan yang lebih rendah, } \\
\text { Merespon positif pelaporan yang }\end{array}$ & $\begin{array}{l}\text { Kepemimpinan yang } \\
\text { kondusif telah diterapkan } \\
\text { dengan baik oleh Dinas } \\
\text { Pekerjaan Umum, serta } \\
\text { objektivitas dijunjung } \\
\text { tinggi khususnya dalam } \\
\text { bidang keuangan, } \\
\text { program maupun } \\
\text { kegiatan. }\end{array}$ \\
\hline
\end{tabular}




\begin{tabular}{|c|c|c|c|}
\hline No. & \multicolumn{2}{|r|}{ PP No. 60 Tahun 2008} & \multirow{2}{*}{ Dinas Pekerjaan Umum } \\
\hline & & $\begin{array}{l}\text { berkaitan dengan keuangan, } \\
\text { program, dan kegiatan. }\end{array}$ & \\
\hline d. & $\begin{array}{l}\text { Pembentukan } \\
\text { struktur } \\
\text { organisasi yang } \\
\text { sesuai dengan } \\
\text { kebutuhan }\end{array}$ & $\begin{array}{l}\text { Menyesuaikan dengan ukuran dan } \\
\text { sifat kegiatan, } \\
\text { Memberikan kejelasan wewenang } \\
\text { dan tanggung jawab, } \\
\text { Memberikan kejelasan hubungan } \\
\text { dan jenjang pelaporan intern, } \\
\text { - Melaksanakan evaluasi dan } \\
\text { penyesuaian terhadap struktur } \\
\text { organisasi, } \\
\text { Menetapkan jumlah pegawai yang } \\
\text { sesuai. }\end{array}$ & $\begin{array}{l}\text { Dalam pelaksanaannya } \\
\text { sudah baik karena } \\
\text { struktur organisasi Dinas } \\
\text { Pekerjaan umum telah } \\
\text { menyesuaikan dengan } \\
\text { ukuran dan sifat } \\
\text { organisasi, tetapi dalam } \\
\text { beberapa bidang } \\
\text { contohnya bidang } \\
\text { keuangan, masih } \\
\text { kekurangan pegawai yang } \\
\text { kompeten dibidangnya. }\end{array}$ \\
\hline e. & $\begin{array}{l}\text { Pendelegasian } \\
\text { wewenang dan } \\
\text { tanggung jawab } \\
\text { yang tepat }\end{array}$ & $\begin{array}{l}\text { Wewenang diberikan kepada } \\
\text { pegawai yang tepat, } \\
\text { Pegawai yang diberikan wewenang } \\
\text { memahami bahwa wewenang dan } \\
\text { tanggung jawab yang diberikan } \\
\text { terkait dengan pihak lain, } \\
\text { Pegawai yang diberi wewenang } \\
\text { memahami bahwa pelaksanaan } \\
\text { wewenang dan tanggung jawab } \\
\text { terkait dengan penerapan SPIP. }\end{array}$ & $\begin{array}{l}\text { Pendelegasian wewenang } \\
\text { dan tanggung jawab telah } \\
\text { dilaksanakan dengan baik } \\
\text { oleh Dinas Pekerjaan } \\
\text { Umum. Pegawai yang } \\
\text { diberikan wewenang } \\
\text { memahami dengan baik } \\
\text { jelas dan tanggung } \\
\text { jawabnya serta } \\
\text { diberdayakan untuk } \\
\text { menyelesaikan } \\
\text { pekerjaannya. }\end{array}$ \\
\hline f. & $\begin{array}{l}\text { Penyusunan dan } \\
\text { penerapan } \\
\text { kebijakan yang } \\
\text { sehat tentang } \\
\text { pembinaan } \\
\text { sumber daya } \\
\text { manusia. }\end{array}$ & 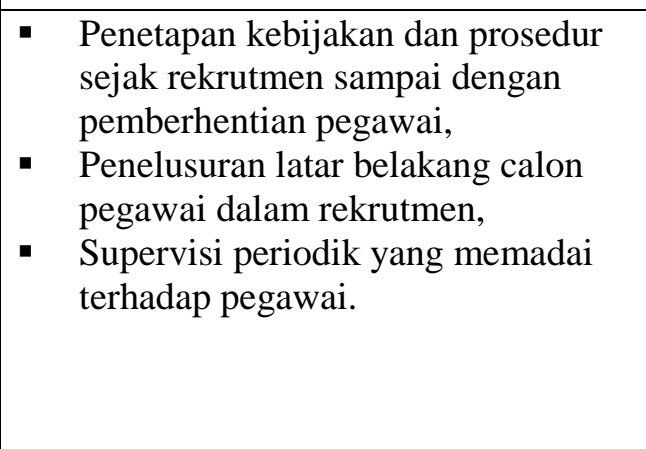 & $\begin{array}{l}\text { Sudah dilaksanakan } \\
\text { dengan baik, hal ini } \\
\text { terbukti lewat } \\
\text { penyusunan dan } \\
\text { penerapan kebijakan } \\
\text { pembinaan sumber daya } \\
\text { manusia yang } \\
\text { berpedoman pada } \\
\text { peraturan perundang- } \\
\text { undangan. }\end{array}$ \\
\hline g. & $\begin{array}{l}\text { Perwujudan } \\
\text { peran aparat } \\
\text { pengawasan } \\
\text { intern } \\
\text { pemerintah yang } \\
\text { efektif }\end{array}$ & $\begin{array}{l}\text { Memberikan keyakinan yang } \\
\text { memadai atas ketaatan, kehematan, } \\
\text { efisiensi, dan efektivitas pencapaian } \\
\text { tujuan penyelenggaraan tugas, } \\
\text { Memberikan peringatan dini dan } \\
\text { meningkatkan efektivitas } \\
\text { manajemen risiko dalam } \\
\text { penyelenggaraan tugas dan fungsi, } \\
\text { Memelihara dan meningkatkan } \\
\text { kualitas tata kelola penyelenggaraan } \\
\text { tugas dan fungsi. }\end{array}$ & $\begin{array}{l}\text { Belum dilaksanakan } \\
\text { dengan baik karena, } \\
\text { Dinas pekerjaan Umum } \\
\text { tidak memiliki aparat } \\
\text { pengawasan Intern tetapi } \\
\text { Dinas pekerjaan Umum } \\
\text { menjunjung ketaatan, } \\
\text { kehematan, efisiensi, dan } \\
\text { efektivitas dalam } \\
\text { mencapai tujuan instansi } \\
\text { serta memperhatinan } \\
\text { manajemen risiko dalam } \\
\text { penyelenggaraan tugas. }\end{array}$ \\
\hline h. & $\begin{array}{l}\text { Hubungan kerja } \\
\text { yang baik } \\
\text { dengan instansi } \\
\text { pemerintah }\end{array}$ & $\begin{array}{l}\text { Adanya mekanisme saling uji antar } \\
\text { Instansi Pemerintah terkait. }\end{array}$ & $\begin{array}{l}\text { Telah dilaksanakan } \\
\text { dengan baik. Pimpinan } \\
\text { Dinas pekerjaan umum } \\
\text { memiliki hubungan kerja }\end{array}$ \\
\hline
\end{tabular}




\begin{tabular}{|c|c|c|c|}
\hline No. & \multicolumn{2}{|r|}{ PP No. 60 Tahun 2008} & Dinas Pekerjaan Umum \\
\hline & terkait & & $\begin{array}{l}\text { yang baik dengan instansi } \\
\text { pemerintah yang } \\
\text { mengelola anggaran, } \\
\text { serta melakukan } \\
\text { pembahasan secara } \\
\text { berkala tentang pelaporan } \\
\text { keuangan. }\end{array}$ \\
\hline 2. & $\begin{array}{l}\text { Penilaian } \\
\text { Risiko }\end{array}$ & & \\
\hline a. & $\begin{array}{l}\text { Identifikasi } \\
\text { risiko }\end{array}$ & $\begin{array}{l}\text { Menggunakan metodologi yang } \\
\text { sesuai untuk tujuan instansi } \\
\text { penerintah } \\
\text { Menggunakan mekanisme yang } \\
\text { memadai untuk mengenali risiko } \\
\text { dari faktor internal maupun } \\
\text { eksternal. } \\
\text { Menilai faktor lain yang dapat } \\
\text { meningkatkan risiko. }\end{array}$ & $\begin{array}{l}\text { Dalam pengidentifikasian } \\
\text { risiko,sudah dilaksanakan } \\
\text { dengan baik. Pimpinan } \\
\text { instansi menetapkan } \\
\text { tujuan instansi dengan } \\
\text { berpedoman pada } \\
\text { peraturan perundang- } \\
\text { undangan, serta } \\
\text { menetapkan strategi dan } \\
\text { rencana penilaian risiko. }\end{array}$ \\
\hline b. & Analisis risiko & $\begin{array}{l}\text { Dilaksanakan untuk menentukan } \\
\text { dampak dari risiko yang telah } \\
\text { diidentifikasi terhadap pencapaian } \\
\text { tujuan Instansi Pemerintah. }\end{array}$ & $\begin{array}{l}\text { Dalam menganalisis } \\
\text { risiko juga sudah } \\
\text { diterapkan dengan baik, } \\
\text { dimana pimpinan } \\
\text { menerapkan prinsip } \\
\text { kehati-hatian dalam } \\
\text { menentukan tingkat risiko } \\
\text { yang dapat diterima. }\end{array}$ \\
\hline 3. & $\begin{array}{l}\text { Kegiatan } \\
\text { Pengendalian }\end{array}$ & & \\
\hline & $\begin{array}{l}\text { Menyelenggarak } \\
\text { an kegiatan } \\
\text { pengendalian } \\
\text { sesuai dengan } \\
\text { ukuran, } \\
\text { kompleksitas, } \\
\text { dan sifat dari } \\
\text { tugas dan fungsi } \\
\text { Instansi } \\
\text { Pemerintah. }\end{array}$ & $\begin{array}{l}\text { - } \text { Reviu atas kinerja, } \\
\text { - Pembinaan sumber daya manusia, } \\
\text { Pengendalian atas pengelolaan } \\
\text { sistem informasi, } \\
\text { - Pengendalian fisik atas aset, } \\
\text { Penetapan dan reviu atas indikator } \\
\text { dan ukuran kinerja, } \\
\text { - } \text { Pemisahan fungsi, } \\
\text { Otorisasi atas transaksi dan kejadian } \\
\text { penting, } \\
\text { - } \quad \text { Pencatatan yang akurat dan tepat } \\
\text { waktu atas transaksi dan kejadian, } \\
\text { - } \begin{array}{l}\text { Pembatasan akses atas sumber daya } \\
\text { dan pencatatannya, dan }\end{array} \\
\text { - } \text { Dokumentasi yang baik atas SPI } \\
\text { serta transaksi dan kejadian penting. }\end{array}$ & $\begin{array}{l}\text { Penyelenggaraan } \\
\text { kegiatan pengendalian } \\
\text { telah dilaksanakan } \\
\text { dengan baik oleh Dinas } \\
\text { Pekerjaan Umum } \\
\text { Provinsi Sulawesi Utara, } \\
\text { dinas pekerjaan umum } \\
\text { terbagi dalam beberapa } \\
\text { bidang fungsi yang } \\
\text { berbeda, adanya tolok } \\
\text { ukur penilaian yang } \\
\text { dijadikan pedoman untuk } \\
\text { meriviu kinerja para } \\
\text { karyawan, dilakukan } \\
\text { pembinaan sumber daya } \\
\text { manusiademi mendukung } \\
\text { pencapaian tujuan, serta } \\
\text { dilakukan otorisasi atas } \\
\text { transaksi keluar masuk } \\
\text { uang dan kejadian } \\
\text { penting berdasarkan } \\
\text { aturan yang berlaku. }\end{array}$ \\
\hline 4. & $\begin{array}{l}\text { Informasi dan } \\
\text { Komunikasi }\end{array}$ & & \\
\hline
\end{tabular}




\begin{tabular}{|c|c|c|c|}
\hline \multirow[t]{2}{*}{ No. } & \multicolumn{2}{|r|}{ PP No. 60 Tahun 2008} & \multirow[b]{2}{*}{$\begin{array}{l}\text { Dinas Pekerjaan Umum } \\
\text { Sudah dilaksanakan } \\
\text { dengan baik. Informasi } \\
\text { tentang tujuan instansi } \\
\text { dikomunikasikan dengan } \\
\text { jelas kepada seluruh } \\
\text { pegawai, dan disediakan } \\
\text { tepat waktu agar dapat } \\
\text { dilaksanakan } \\
\text { pemantauan, dan bila } \\
\text { perlu dikoreksi secara } \\
\text { cepat dan tepat. }\end{array}$} \\
\hline & $\begin{array}{l}\text { Mengidentifikas } \\
\text { i, mencatat, dan } \\
\text { mengkomunikas } \\
\text { ikan informasi } \\
\text { dalam bentuk } \\
\text { dan waktu yang } \\
\text { tepat. }\end{array}$ & $\begin{array}{l}\text { Menyediakan dan memanfaatkan } \\
\text { berbagai bentuk dan sarana } \\
\text { komunikasi, dan } \\
\text { Mengelola, mengembangkan, dan } \\
\text { memperbaharui sistem informasi } \\
\text { secara terus-menerus. }\end{array}$ & \\
\hline 5. & Pemantauan & & \\
\hline & $\begin{array}{l}\text { Pemantauan } \\
\text { Sistem } \\
\text { Pengendalian } \\
\text { Intern. }\end{array}$ & $\begin{array}{l}\text { Dilaksanakan melalui pemantauan } \\
\text { berkelanjutan, evaluasi terpisah, dan } \\
\text { tindak lanjut rekomendasi hasil audit } \\
\text { dan reviu lainnya. }\end{array}$ & $\begin{array}{l}\text { Pemantauan telah } \\
\text { dilaksanakan dengan baik } \\
\text { dan dengan dilakukan } \\
\text { secara berkala, juga } \\
\text { dilakukan evaluasi secara } \\
\text { berkala segala kegiatan } \\
\text { pengendalian yang } \\
\text { mendukung pencapaian } \\
\text { tujuan organisasi. }\end{array}$ \\
\hline
\end{tabular}

C. Evaluasi Anggaran dan Realisasi Belanja Dinas Pekerjaan Umum Provinsi Sulawesi Utara.

Berdasarkan hasil penelitian, dapat diketahui bahwa pada tahun 2013 realisasi belanja Dinas Pekerjaan Umum mencapai angka 91,89\%, pada tahun 2014 mencapai angka $82,63 \%$ dan pada tahun 2015 mencapai angka 96,77\%.

Jadi sistem Pengendalian Intern (Internal Control) dalam pengelolaan anggaran belanja Dinas Pekerjaan Umum Provinsi Sulawesi Utara sudah baik.Dengan sistem pengendalian intern yang baik, maka kecurangan dapat dihindari.

\section{KESIMPULAN DAN SARAN}

\subsection{Kesimpulan}

Berdasarkan hasil penelitian dan pembahasan yang dilakukan, maka dapat disimpulkan bahwa :

1. System pengendalian internal yang diterapkan oleh Dinas Pekerjaan Umum Provinsi Sulawesi Utara telah efektif dan memadai.

2. Pembagian wewenang dan tanggung jawab sudah efektif dilakukan oleh dinas Pekerjaan Umum Provinsi Sulawesi Utara.'

3. Realisasi belanja Dinas Pekerjaan Umum Provinsi Sulawesi Utara dari tahun 2013 sampai tahun 2015 sudah efektif.

\subsection{Saran}

1. Sebaiknya Dinas Pekerjaan Umum membentuk badan audit Pengendalian Internal dinas yang bertugas untuk mengaudit segala kinerja dinas dan mempersiapkan dinas dalam pengawasan eksternal.

2. Sebaiknya dinas lebih memperhatikan jumlah Sumber Daya Manusia yang ada di setiap bidang yang masih membutuhkan tambahan pegawai demi peningkatan kinerja dinas. 


\section{DAFTAR PUSTAKA}

Hery, 2014. Mahir Accounting Principles. Grasindo. Jakarta

Mursyidi,2013.Akutansi pemerintahan di Indonesia. Refika Aditama. Bandung

Sugiyono, 2014, Metode Penelitian Kuantitatif Kualitatif dan R\&D, Bandung: Alfabeta.

Suwardjono, 2014. Akuntansi pengantar. BPFE. yogyakarta.

Torang, Syamsir. 2013. Organisasi dan Manajemen. Alfabeta. Bandung

Rina, 2012. Pengaruh efektivitas pengendalian intern terhadap kinerja instansi pemerintah di Dinas Pendapatan Daerah Kota Bandung. Universitas Widyamata.

Rini, Ongki. 2013. Pengaruh audit manajemen dan pengendalian intern terhadap kinerja perusahaan dengan good corporate governance sebagai variabel intervening (studi pada PT.Jamsostek (Persero) Divisi Regional VI Jawa Timur). STIE Malangkucecwara. Malang.

Rizki, 2013. Pengaruh efektivitas pengendalian intern, asimetri informasi dan kesesuaian kempensasi terhadap kecenderungan kecurangan akuntansi (Fraud). Universitas Negeri Padang.

Sarita, 2012. Pengaruh pengendalian internal dan gaya kepemimpinan terhadap kinerja karyawan SPBU Yogyakarta (Studi kasus pada SPBU anak cabang perusahaan RB.Group). Universitas Negeri Yogyakarta. Yogyakarta.

Suwardjono, 2014. Akuntansi pengantar. BPFE. yogyakarta.

TMBooKS, 2015. Sistem informasi Akutansi. Andi : Yogyakarta

Zhu, Sun, 2017. The impact of coupling interaction of internal control and CSR on corporate performance - Based on the perspective of stakeholder. Zhengzhou University. China. 